\title{
Interrupter Technique
}

National Cancer Institute

\section{Source}

National Cancer Institute. Interrupter Technique. NCI Thesaurus. Code C124352.

A non-invasive method of measuring airway resistance during which the subject breathes normally while airflow is interrupted at a predetermined rate and volume during the early exhalation phase. Airway resistance is calculated as the ratio of alveolar pressure, which is estimated from mouth pressure during occlusion, to airflow before interruption. This method is used most often in children and other subjects unable to comply with instructions for conventional lung function tests. 